\title{
Zsolt Sógor
}

\section{Beckett between the Lines}

\section{From Murphy to Watt}

\begin{abstract}
This paper wishes to analyse two early novels by Samuel Beckett; Murphy and Watt. It takes a chronological point of view from which it argues that the later of the two, Watt, is closer to Beckett's mature voice, mainly due to its relation with language. This means, in other words, that though in Murphy quite a lot of emphasis is to fall on the role of language, in Watt, with a bit of exaggeration, there is hardly anything else to concentrate on but the language of the novel and language as such in general. The emphasis on language leads to considering Beckett's relation to languages. Since Watt was for a long time the last longer prose work that Beckett wrote in English, the paper regards this novel as a harbinger of the approaching change for French. Or rather, the approaching bilingual state, because, as it is argued, Beckett may be said to have been approaching an in-between state in, or beyond, the two languages of composition. Taking the author's bilingualism into consideration means, however, an author-oriented approach - this is what the paper undertakes to present; to find Beckett's fingerprints between the lines.
\end{abstract}

Reading Samuel Beckett's Watt might be enjoyable for a number of reasons. We find, for instance, a unique model for entering a house:

Finding the door locked, Watt went to the back door. He could not very well ring, or knock, for the house was in darkness.

Finding the back door locked also, Watt returned to the front door.

Finding the front door locked still, Watt returned to the back door.

Finding the back door now open, oh not open wide, but on the latch, as the saying is, Watt was able to enter the house. ${ }^{1}$

Obviously it would be too simple if meanwhile someone had opened the door; Watt is to find no one in who could have done so. How, then, was he able to get in? To my

1. Samuel Beckett, Watt (London: John Calder, 1963), pp. 34-35.

The AnaChronisT 10 (2004): 80-96 ISSN 1219-2589 
mind, the best way to find an explanation is to leave this narrative and have a look at a similar problem in Beckett's previous novel, Murphy. In that work we face an inexplicable and unexplained fact already on the first page, where Murphy is shown sitting in his rocking chair, tied up:

Seven scarves held him in position. Two fastened his shins to the rockers, one his thighs to the seat, two his breast and belly to the back, one his wrists to the strut behind. Only the most local movements were possible. ${ }^{2}$

The seven scarves are six, which might even be a simple mistake (though it is retained in Beckett's own French translation); however, another insoluble question is bound to remain, as we learn later that it was himself who tied the scarves: how did he tie himself up? We are not to know. The only solution of the riddle is to place oneself out of the level of the narrative and accept that what we are reading is a work of art, where anything may happen. With Watt's footnote remark: "Haemophilia is, like enlargement of the prostate, an exclusively male disorder. But not in this work." $\mathrm{A}$ door that is locked cannot normally be open a minute later without any external assistance, it can, however, be so "in this work."

In a way, the external assistance is that of the narrator and that of the reader; the former "lets Watt in" as this is a pre-requisite of the novel's structure and the events to follow, the latter, if intending to remain a reader till the end, cannot but simply accept that Watt could enter the house somehow. The critic John Mood discovered twenty-eight similar inconsistencies in Watt ${ }^{4}$ - the number itself suggests that the reader should get accustomed to the phenomenon after a while. The narrator is aware of producing a novel and is ready to go to any lengths in order to make the reader realise this.

Murphy and Watt have this, and a lot more, in common. There are, nevertheless, significant differences as well. Both are worth examining, in my opinion, as the two novels together may throw some light on what was to remain and what to disappear in Beckett's world for the later, more highly appreciated works. This argument, of course, assumes that there is a sort of linear development in Beckett's writings and that a certain work could be regarded as a successor of the former ones, meaning, practically, that the works bearing the name 'Samuel Beckett' on their covers constitute one com-

2. Samuel Beckett, Murphy (London: John Calder, 1993), p. 5.

3. Watt, p. 100.

4. John Mood quoted in Rubin Rabinovitz, The Development of Samuel Beckett's Fiction (Chicago: University of Illinois Press, 1984), p. 119. 
plex oeuvre, in which each piece has its place. This may easily seem an oversimplification of the matter, yet I agree with the critics arguing that there is truth in it.

The concluding chapter of Rubin Rabinovitz's book devoted to Beckett's fiction, for example, was given the following title: "The Deterioration of Outer Reality in Beckett's Fiction," 5 pointing out that precise, identifiable places and names disappeared from Beckett's works with time, leading to a closed inner world. But place names are just a part of the process; put in a more general form he states that: "As Beckett's career developed, he began to abandon the dense, learned style that characterized his early works."6 Lawrence E. Harvey, analysing Beckett's poetry, talks about Beckett's gradual "withdrawal from the macrocosm into the microcosm of the mind"7 as the central experience of his poetry. Hélène L. Baldwin divides Beckett's career into four periods, out of which the first, she claims, is full of word plays and overt satire, while the second already, due to "the sobering works of the Resistance," 8 brings a clearer, less ornamented style. André Topia goes as far as to talk about Murphy as "Beckett baroque,"9 claiming that "the emergence of the voice aims to make all the unevenness and baroque flourish of the beginnings disappear gradually."10

Another critic, Leslie Hill, brings a counter-argument, by demanding more attention to the early works for their own sake:

To take Beckett's early work, the essays on Joyce or Proust, the stories in More Pricks than Kicks or the novel Murphy, as being important for what they tell us about Beckett's better known later writings, is to grant these early works secondary status, while still maintaining that they contain more transparent evidence of the author's underlying intentions and his formative (yet already formed) ideas. The contradiction seems plainly untenable. ${ }^{11}$

5. Rabinovitz, p. 176.

6. Rabinovitz, p. 176.

7. Lawrence E. Harvey, Samuel Beckett: Poet and Critic (Princeton: Princeton University Press, 1970), p. 184.

8. Hélène L. Baldwin, Samuel Beckett’s Real Silence (University Park: The Pennsylvania UP, 1981), p. 163.

9. André Topia, "Murphy ou Beckett baroque," in Beckett avant Beckett, ed. Jean-Michel Rabaté (Paris: P.E.N.S., 1984), 93-119.

10. "[L]'émergence de la voix aboutit à gommer peu à peu toutes les aspérités et les efflorescences baroques du début" (Topia, p. 94; all the translations, if not otherwise noted, are my own).

11. Leslie Hill, Beckett's Fiction in Different Words (Cambridge: Cambridge UP, 1990), p. 1. 
It seems tenable to me, since I see no contradiction in the ideas having been formed well before they could gain a finally satisfactory form. In other words, just because later works show no sign of a clear authorial intention, they may be according to such intentions, those intentions probably aiming exactly at disposing of anything easily identifiable. Also, it may be imagined even without mentioning intentions at all that the signs of what later works of art will contain are clearly present in earlier ones.

Returning now to Murphy and Watt, I will attempt to search for those early signs of the later voice. By doing so, I must admit, I will hardly hit upon anything that has been left unsaid so far, critics have thoroughly treated not only these two novels but also an alarmingly large number of possible inferences. The reason for which I still do not consider my analysis totally redundant is that I will attempt to give a complex picture of Beckett's way towards the language of his late works. I would not only like to suggest, on the basis of the two early novels, that Beckett's works concentrated more and more on language, on trying to cease to be language after all, but also that this tendency has a lot to do with the author himself, especially with his bi-, or, possibly, multilingualism. This, I think, might be of interest as Murphy and Watt were both written before Beckett started writing in French and also because the author is not taken as a source in the analysis; on the contrary, the examination of the language of the two novels draws attention to the unique linguistic situation of the author.

On the basis of chronology it is to be expected that Watt, completed in 1945, nine years after Murphy (but published fifteen years later than the other novel), is closer to the mature Beckett, and, to my mind, this is what one can find. What disappeared after Murphy were, for instance, the already mentioned place names. It was quite usual for the early Beckett texts to be full of references to the outside world, it is hardly surprising that John Pilling should point out how "Murphy builds handsomely on its predecessor [More Pricks than Kicks] in its presentations of what Murphy calls 'the big world.' "12 It is worth noting that Murphy's big world is in fact

quite small, for all practical purposes bounded by West Brompton, South Kensington, the Caledonian Road and - full of Eastern promise - the mental asylum 'a little way out of town ... on the boundary of two counties' (in real life the Maudsley Hospital at Beckenham). ${ }^{13}$

12. John Pilling, "Beckett's English Fiction," in The Cambridge Companion to Beckett, ed. John Pilling (Cambridge, CUP, 1994), 17-42, p. 33.

13. Pilling, p. 33 . 
The point is not the actual size of the big world, much rather the later unusual real geographical basis; even the MMM, Murphy's mental hospital has an existing model. Interestingly enough for an Irish writer, Dublin's importance in the novel is nowhere near that of London; it appears "as if Beckett's sojourn in London had compelled him, in spite of his personal difficulties there, to register its existence. (Beckett's native Dublin, by contrast, is merely a shadowy elsewhere. . .)."14

Another substantial feature is the novel's novel-identity. Watt, and the later sizeable prose works do not build on traditions to a great degree, their experimental nature gives way at most to a sort of anti-novelish character - being attached to traditions by turning against them. (The French nouveau roman is of course a literary tradition with which Beckett's prose is connected, it was not yet shaped as such, though, at the time of Beckett's writing Watt.)

Murphy, on the other hand, feeds on a number of literary traditions, even if very often it presents a rather satiric view of them. The connection is not only created by occasional references, such as Murphy "never ripped up old stories," 15 or the novel's first sentence: "The sun shone, having no alternative, on the nothing new,"16 where "nothing new" may be understood as "scouting the very idea of the novel as something new."17 In Murphy "Beckett adopted pre-existent structures and strategies, almost all of which can be found in Cervantes and the English novelists of the eighteenth century." 18 The novel's 'realism' (i.e. the connection with the "big world"), the narrator's commenting on the events, or the summarizing, interpreting chapter (in Murphy chapter six) are all instances of such strategies.

The immense quantity and diversity of parody elements connects Murphy to the "great tradition that D.W. Jefferson called, in connection with Sterne (another Irishman), 'learned wit' embodied by Rabelais, Jonson, Donne, Swift, Sterne."19 Stylistic ornamentation in general is highly characteristic of Murphy, meaning thereby the usage and parody of scientific and technical languages (André Topia counts ten different disciplines mocked), flourishing sentences, countless verbal and structural repetitions, word plays and the coinage of new words. Also, there is a narrator who is

\footnotetext{
14. Pilling, p. 33.

15. Murphy, p. 14.

16. Murphy, p. 5 .

17. Pilling, p. 30.

18. Pilling, p. 29.

19. "Tout ce recours systématique à une érudition parodique inscrit Murphy dans la grande tradition de ce que D.W. Jefferson a appelé à propos de Sterne (autre Irlandais) le 'learned wit' (érudition parodique) illustré par Rabelais, Jonson, Donne, Swift, Sterne” (Topia, p. 112).
} 
always eager to comment on characters, events - again a factor that might be considered to reach back to Sterne or Fielding.

This can also be seen from a different point of view: the questioning of the characters' own existence, the utter reliance on the narrator points forward to the later prose works. As far as narrating is concerned, Murphy clearly shows the importance of the experimentalist's basic question (coming from Mr. Kelly's mouth when Celia relates the story of her getting acquainted with Murphy):

‘How do you know all this?' said Mr. Kelly.

'What?' said Celia.

'All these demented particulars,' said Mr Kelly. ${ }^{20}$

The narrator's insisting on knowing all the particulars, "on always recalling the umbilical cord that attaches them [the characters] to him, anticipates a novel like Malone Dies where the characters are never more than fiction created by a creator's arbitrary decision." ${ }^{21}$

Within the novel itself, using Murphy's terminology, the key element is retraction from his "big world" into his "little world." It is the little one where Murphy is said to find happiness, yet, he cannot fix himself there, being too much bound by the other one. As mentioned above, Murphy is seen for the very first time tied up in his rocking chair, where he faintly hears "the echo of a street cry, which now ... gave Quid pro quo! Quid pro quo! directly." 22 A couple of pages later Murphy again concentrates on the rhythm of the rocking chair: "Slowly the world died down, the big world where Quid pro quo was cried as wares and the light never waned the same way twice; in favour of the little, as described in section six, where he could love himself." ${ }_{23}$

Great indeed, but why should anyone shout Quid pro quo in the street? Assuming that the expression (something for something else, usually for a false representation) does not appear out of sheer eccentricity, its role seems worth pondering over a little. On the one hand, it is useful as a queer sounding expression occurring in the English text, standing, after all, in place of an English equivalent itself. More than that, however, it practically becomes the motto of the big world from which Murphy

20. Murphy, p. 12.

21. "[C]ette insistance à toujours rappeler le cordon ombilical qui les rattache à lui anticipe un roman comme Malone meurt où les personnages ne sont jamais que des fictions créées par la décision arbitraire d'un créateur qui leur a donné naissance mais peut aussi bien décider de les détruire" (Topia, p. 101).

22. Murphy, p. 5 .

23. Murphy, p. 8. 
strives to escape. This might mean that this big world, i.e. 'reality,' is a false representation of an inner world, or rather that it simply does not know what it stands for. Murphy tries not to be a part of all this, he "is fundamentally out of step with the world," which suggests to him "the contingency of human connections, and hence, the commodification or public trading of the self." 24

Taking into account the role of language in Murphy, however, it is possible to go even farther. Throughout the whole novel, the consciousness of the story's being language is to be seen. When Neary talks to him about love requited, describing it as "the single, brilliant, organized, compact blotch in the tumult of heterogeneous stimulation," Murphy's response is to the point: "Blotch is the word." 25 It is no surprise, consequently, that when Celia, Murphy's lover, being disappointed by Murphy's reluctance to start working says: "'I'll be sorry I met you'," Murphy should once again reply: “'Met me!' said Murphy. 'Met is magnificent.' "26

Murphy seems to be what his words are, though this is, according to Celia, not necessarily a compliment:

She felt, as she felt so often with Murphy, spattered with words that went dead as soon as they sounded; each word obliterated, before it had time to make sense, by the word that came next; so that in the end she did not know what had been said. It was like difficult music heard for the first time. ${ }^{27}$

The novel's being language, what is more, the futility of this language, is also emphasized by the already mentioned focus on technical languages, wordplays and the eternal search for the right word. When Neary and Wylie are trying to find out what it might possibly be that makes Murphy attractive for the other sex, the latter says: " 'It is his -' stopping for want of the right word. There seemed to be, for once, a right word." 28 Then, when after a short silence Wylie is certain to have found the right word ("his surgical quality"), it is the narrator who does not lose a moment to remark: "It was not quite the right word." 29 All in all, I tend to believe that not only Murphy the character, but also Murphy the novel, is what its words are. Any reader-

24. Wendy Foster, "Murphy's Aporia: An Examination of the Spaces of Desire as Structured Absences in Samuel Beckett's Murphy," http://www.themodernworld.com/beckett/paper_foster.html (Accessed on 1st April 2004).

25. Murphy, p. 7.

26. Murphy, p. 25.

27. Murphy, p. 27.

28. Murphy, p. 39.

29. Murphy, p. 39. 
oriented approach would lay much more emphasis on the role of reception. While I must be aware that my reading of these novels is also only one possible reading influenced by a number of critical opinions, I wish, as much as possible, to concentrate on the relationship between the works and the source towards which, as far as I see, they point; language and the author.

'Quid pro quo,' after all, may be taken as the arch structuralist view on the relation of signifier and signified. Murphy is no true structuralist, however, as the tyranny of 'quid pro quo' is what he wants to be released from, he complains exactly about the impossibility to represent. In an early critical essay of his on the painting of the two van Veldes, Beckett formulates the view that

The essence of the object of representation is its unrepresentability.... Beckett suggests that there are now three routes open to art: to return to an old and discredited naivety and to ignore the subject-object problematic; to continue to struggle with the old subject-object relation or the van Veldes' way, which admits defeat but finds a new object in the conditions of unrepresentability. 30

Unrepresentability gains key importance. By bringing Beckett the person into the picture it also throws light on the writer's compulsion to use words for describing what cannot be described by them. "Confronted with a language that lends itself for all the ambiguities and all the mutations, Beckett is going to exploit this original fault and turn it to his advantage." ${ }^{31} \mathrm{He}$ does so exactly by, as seen in the beginning, proving that in the language-tissue of his novel anything "unreal" may happen, as reality is simply not to be described by language; language is not something to describe reality. Murphy's "big world," in the end, might mean language as well to Beckett, from which he struggles to escape into his own "little world." It has to remain impossible, though, to step beyond language while still using it.

The solution might be the same for character and writer alike; to go on, with the famous words of The Unnamable, even if it is not possible to go on. Or, to put it in a more exact form, the solution is Murphy's truncated version of the saying of one of Beckett's favourite philosophers: " 'I am not of the big world, I am of the little world' was an old refrain with Murphy. ... In the beautiful Belgo-Latin of Arnold Geulincx:

30. Rupert Wood, "An Endgame of Aesthetics: Beckett as Essayist," in The Cambridge Companion to Beckett, ed. John Pilling (Cambridge: Cambridge UP, 1994), 1-16, p. 11.

31. "Confronté à un langage qui se prête à toutes les ambiguïtés et à toutes les mutations, Beckett va exploiter cette faille originelle et la tourner à son avantage” (Topia, p. 105). 
Ubi nihil vales, ibi nihil velis." 32 The original Geulincx-saying goes like this: "Ubi nihil vales, ibi etiam nihil velis (want nothing where you are worth nothing)," since "according to Geulincx, because man enjoys true freedom only in the mental world, he would do best to abstain from desiring the things of the physical world." 33

Murphy achieves the Cartesian split of the physical and mental world and would vote for the latter with pleasure, yet he fails because he cannot find the basic method of leaving behind physical bonds: indifference. He is unable to want nothing, as it is best symbolized by his chess-game with Mr. Endon. Mr. Endon is the enigmatic inhabitant of the MMM hospital, the Magdalen Mental Mercyseat, where Murphy is employed as a male nurse and where he gets ever so close to his little world. The final step, however, is beyond him. He wishes to become like Mr. Endon (a telling Beckettian name; end on) and he could do so if only he were able to forget about bonds like the rules of chess. In the party between them (all the steps given in chapter eleven, Murphy with white), Murphy cannot handle Mr. Endon's nonchalance. Once, for example "without as much as 'j'adoube,' [Mr. Endon] turned his King and Queen's Rook upside down, in which position they remained for the rest of the game."34 As a matter of fact, Mr. Endon's "goal is not to win but to arrange his pieces in a pleasing pattern." 35 This indifference concerning winning is what Murphy cannot learn and the result is that he loses and realizes that he is not yet ready to find peace in his little world.

It is at this point that he dies, and dies rather mysteriously. His room, a garret, has a radiator that works with gas, the gas-tap, however, is downstairs in a toilet. There are no stairs, in fact, to this garret, Murphy gets in by climbing up a ladder and pulling it up with him afterwards. The last but one time when Murphy is at home, he wants to turn on the radiator but has to realize that he has forgotten to switch on the gas. He is saved the effort: "Almost at once gas, reminding him that he had forgotten to turn it on, began to pour through the radiator." ${ }^{6}$ Murphy does not start thinking about who might have possibly turned the gas on, but feels "greatly obliged, that he had not to let down the ladder and go and repair his omission." 37

Similarly, after the game of chess with Mr. Endon, he goes home and wishes only to take a quiet ride in his rocking chair, not bothering about the gas once again. Though it is not mentioned that the gas-tap was closed after the previous night spent

32. Murphy, p. 101.

33. Rabinovitz, p. 91.

34. Murphy, p. 137.

35. Rabinovitz, p. 92.

36. Murphy, p. 108.

37. Murphy, p. 108. 
there, it is very likely to have been so, as there had neither been an explosion during Murphy's absence, nor when he lit the candle on his arrival. Murphy thus calmly tied himself up (we still cannot know how) and started rocking in the chair. "The rock got faster and faster, shorter and shorter, the gleam was gone, the grin was gone, the starlessness was gone, soon his body would be quiet." 38 The way Murphy died is suggested by the narrator: "The gas went on in the wc, excellent gas, superfine chaos. Soon his body was quiet." 39

The question is then: who turned on the gas-tap? Rabinovitz has suggestions but also finds that in fact all the characters have their alibis. $4^{\circ}$ My guess is the same as it was with Watt's entering the house; the culprit is the narrator. Murphy had to die as this was in the interest of the novel. He failed to grasp how he could go on, therefore he was lost. What is more, his role seems to have been taken over by another character, the only one who, besides Murphy, had the chance to understand the importance of indifference:

It falls not to Murphy but to Celia to become, or rather for the novel to suggest that she might become, 'a mote in the mind of absolute freedom.' It could almost be said that, without Celia, Murphy would have had no real plot above and beyond that which could be borrowed from 'old stories.' Yet it was by way of Celia that Beckett moved towards the plotlessness of Watt. ${ }^{41}$

Indeed, it is Celia who, already in the middle of the novel, in the small room Murphy and she move into, "achieves a kind of identity with Murphy and his rejection of the 'big world.' Celia becomes a voyeur of life which, seen through the 'small single window' becomes 'condensed,' a fragmentary apperception." 42 In the end it is she again who can indifferently return to her profession (a prostitute, almost naturally with Beckett) and wheel her father, Mr. Kelly, so that he can happily fly his kite. The concluding lines of the novel, then, show her identifying with the impenetrable peace of the 'little world': "The yellow hair fell across her face. The yachting-cap clung like a clam to the skull. The levers were the tired heart. She closed her eyes. All out."43

38. Murphy, pp. 141-142.

39. Murphy, p. 142.

40. Rabinovitz, pp. 113-115.

41. Pilling, p. 35.

42. Foster.

43. Murphy, p. 158. 


\section{Watt is the difference?}

All out - thus Murphy ends. And Watt already does not begin with all in. As mentioned above, one of the crucial differences between the two novels is the lack of precise, identifiable places in the later one. The effacement of these names is of course not complete (nor is it in still later works), yet the stress falls on a world that has no real connection with anything like outer reality. Watt is a strictly structured novel, the protagonist is first to go to Mr. Knott's house, second, to be a junior servant on the first floor, third, to be a senior servant on the second floor, and fourth, to leave Mr. Knott's house and return to the station from where he had set off. It is interesting enough, then, that the first part of the novel, in which we find the single identifiable place of the whole work, "was written after the central body of material, a fact that in itself compels some revaluation." 44 This first section

has often been seen as the portion of Watt closest to Murphy and as therefore preceding the increasingly subjective and interiorised passages at Mr. Knott's. Doubtless this is the impression that Beckett wanted to give, since he deliberately frames his 'inner' narrative in the outer sections by the canal and at the station, making the reader experience with Watt the plunge into, and out of, the inner world of Knott's house. 45

Mr. Knott's house is, after all, a sort of nowhere, arguably the very thing that Murphy and Watt have been craving for, as Knott himself embodies unattainability and indifference. Thus, once again, it is not the protagonist who represents the wished-for state of being beyond the "big world." Murphy and Watt are much alike, to dwell on further similarities, both of them are rather queer to look at. "Seen from above and behind," the narrator informs us, "Murphy did look fairly obliging," 46 though one of the chandlers who saw him has an alternative opinion: “ 'E don't look rightly human to me." 47 As for Watt, "Mr. Hackett was not sure that it [Watt] was not a parcel, a carpet, for example, or a roll of tarpaulin." 48 "Like a sewer-pipe, said Mrs. Nixon. Where are his arms?" 49 Also, both of them may be said to be true Cartesians, Murphy

44. Ann Beer, "Watt, Knott and Beckett's Bilingualism,” Journal of Beckett Studies 10 (1985) 37-75.

45. Beer, p. 51.

46. Murphy, p. 57.

47. Murphy, p. 47.

48. Watt, p. 14.

49. Watt, p. 16. 
in realizing the split of the body and the mind, Watt in representing now the mind only, and applying rationalism, exclusively on the basis of what he can see, for all problems. His, and all the other characters', eagerness to examine every trifle in full detail gives the basic tone of the book - the parody of rational thinking and of language hand in hand with it. A short passage from Arsene, Watt's predecessor in the house, on Mr. Knott's habits in selecting his servants might suffice for tasting:

For though it is rumoured that Mr. Knott would prefer to have no one at all about him, to look after him, yet since he is obliged to have someone at all about him, to look after him, being quite incapable of looking after himself, then the suggestion is that what he likes best is the minimum number of small fat shabby seedy juicy bandy-legged pot-bellied pot-bottomed men about him, to look after him, or, failing this, the fewest possible big bony seedy shabby haggard knock-kneed rotten-toothed red-nosed men about him, to take care of him, though at the same time it is freely hinted that in default of either of these. . .50

Characteristically enough this sentence runs on and on listing variants, types and names of servants. It is not difficult to see that a book containing two hundred pages full of sentences like this one is scarcely a traditional novel. It is, "by any standards, distinctly odd, arguably the oddest of all Beckett's works, whether in prose or drama." ${ }^{1}$ This book, too, may be attached to the Sternian tradition to some degree; on the basis of the use of the narrator as well as some typographical surprises. The narrator is first omniscient, then, after some hundred and fifty pages, suddenly identifies himself as Sam, an ordinary character. Also, a musical score (with lyrics, naturally) is inserted when Watt is listening to a choir of birds and other animals in the ditch. A less wellknown tradition to refer to here is the 'Big House' novel; as John Harrington writes

Watt makes use of several staples of the 'Big House' novel: mistreated servants, including Watt; the questionable morals of a local fisherman's wife, Mrs Gorman; the shiftlessness of a pair of local workmen, 'the Galls, father and son'; and the physical misery of a diseased but prolific peasant family named Lynch. ${ }^{2}$

5o. Watt, pp. $57-58$.

51. Pilling, p. 35.

52. John Harrington quoted in James M. Cahalan, The Irish Novel (Dublin: Gill and Macmillan Ltd. 1988), p. 251. 
Yet the differences between Murphy and Watt are a lot more noteworthy than the similarities. Perhaps the single most important point, as far as the characters are concerned, is that Watt, unlike Murphy, "has reached the freedom of indifference" in the end, when there are "no desires left." 53 In the end, that is, after leaving Mr. Knott's house, he is able to give up the wish to understand things and to indulge happily (that is, indifferently) in contemplation - in other words he manages to become a Mr. Endon at last.

If the style carries out a Cartesian parody, this freedom from desire may be the influence of Schopenhauer's or Dante's.54 Dante may also be influential as regards language and the already mentioned signifier-signified relation, since for him

[t]o the concept of sign there always has to belong an only. Man can only know deeper truth by means of signs, what is more, he is not even able to express everything - for example the experience of the mystic - with their help. (One of the basic traits of Danteian poetics derives from here: the thematization of the "ineffable," the idiosyncratic allegorism of the attempt at uttering the in "effable.") 55

It also seems remarkable that in the passage from Dante's Inferno which János Kelemen analyses (Inferno XIII) with respect to references to language, "the state of suffering is identified with the discord of voices and languages described in the scene. It is important to emphasize the distinction: language here does not simply express suffering, it is suffering itself." 56

So is it in Watt. As discussed above, the realm of 'quid pro quo' was already for Murphy a world to flee from. Watt has the same experience but even more forcefully, his permutations show what is possible in language, how with words he can try to find some meaning, and how inevitably he has to fail with his method. Watt needs to

53. Rabinovitz, p. 138.

54. Rabinovitz, pp. 134-138.

55. “A jel-fogalom mellé Danténál mindig odakívánkozik a csak. Az ember csak jelek révén ismerheti meg a mélyebb igazságot, sőt nem is tud a segítségükkel mindent - például a misztikus élményt - kifejezni. (Innen ered a dantei poétika egyik alapvonása: a "kimondhatatlan" tematizálása és a "kimondhatatlan" kimondásának kísérletét jelentő sajátos allegorizmus)" (Kelemen János, A filozófus Dante [Dante, the philosopher] [Budapest: Atlantisz, 2002], p. 104).

56. “[A] szenvedés állapota mintegy a jelenetben leírt nyelv- és hangzavarral azonosul. Fontos hangsúlyoznunk a distinkciót: a nyelv itt nem egyszerúen kifejezi a szenvedést, hanem a szenvedés maga" (Kelemen, p. 127). 
get close to Mr. Knott, "what Watt's cryptic words ... stress is the desire for fusion with Knott." ${ }^{57} \mathrm{He}$ wishes to reach and become that something beyond all thought, all language, that nothing, probably, which is represented by Knott. Yet his thinking in language will keep him far from that which is incomprehensible by means of language. His suffering, his failure is in language, he understands Mr. Knott only when he leaves him, after he stops thinking about him, only when Mr. Knott becomes an absence for him. Because Mr. Knott, the end of all Watt's desires, is absence, the freedom from the obligation of presence. Mr. Knott is unrepresentable, that is why the method to reach him can again only be indifference and the absence of desire.

It is certain, at least, that Watt is in need of another language, "as he speaks in riddles, [he] seems to express the desire for another tongue in which it would be possible to speak something other than what is available in his original language." 58 As Watt was, for more than a decade, the last prose work that Beckett wrote in English, Watt's wish to go beyond language, to prove its utter futility may even be regarded as reflecting Beckett's own feelings at that time.

Already in Dream of Fair to Middling Women, a "pot-pourri of volatile but irreconcilable elements, part-autobiography, part-fiction, and part-looseleaf folder for any passing expressive gesture" 59 written before Murphy, Beckett writes on Racine and Malherbe: "They have no style, they write without style, do they not, they give you the phrase, the sparkle, the precious margaret. Perhaps only the French language can do it. Perhaps only the French language can give you the thing you want."6o Indeed, if one thinks of the appreciation Beckett was given in France for his trilogy and of course with the original French Waiting for Godot and Endgame, the above statement appears to be literally true.

Watt is, however, an English book. Yet, it has a sort of transitory character, it presses the problematic of language so much that the reader is bound to feel some doubt at least concerning language. Ann Beer, dealing extensively with Beckett's bilingualism, also throws light on why Watt can already be regarded as partly a French book. She claims that in Watt Beckett's altered relation to English can be discovered, what is more, this is the book that "reveals the pressure of bilingualism in its most acute form in Beckett's works." 61 Beer draws a parallel between Beckett's externalization of English in this work and the function of the two languages in the bilingual mind: the languages are seen as different codes, and have far less reliability

57. Hill, p. 35 .

58. Hill, p. 35 .

59. Pilling, p. 20.

6o. Quoted in Rabinovitz, p. 179.

61. Beer, p. 37. 
than does his or her only language for the monolingual person. She then goes on to argue that, when writing Watt, Beckett had already been under the influence of French (the time of writing is 1941-1945, when Beckett already lived in France and assisted the Resistance) as can be seen from the French marginalia, the large number of sentences having a French-like word order and so on.

To my mind her evidence is totally convincing, yet once again I find it necessary to refer to the question of the author. That Beckett, the writer, and his bilingualism may be the cause of Watt the novel's queer experiments with language can hardly pass as a fashionable idea in recent literary thinking. Nevertheless, a lot of valuable insights would be lost were we to utterly dismiss the writer's situation and intentions from analysis. Interestingly enough, especially after talking about Beckett's lurking behind the problems of unrepresentability in his novels, Sean Burke, on reacting to the work of Barthes, Foucault and Derrida, is ready to go as far as to declare that "what Roland Barthes has been talking of all along is not the death of the author, but the closure of representation." ${ }^{2} \mathrm{He}$ bases his argument, after pointing to a number of contradictory ideas in "The Death of the Author" and $S / Z$, mainly on Barthes' Sade Fourier Loyola, where Barthes himself talks about the return of the author in the cases of the three title authors. The inference is that "if a text has been 'unglued' of its referentiality, its author need not die; to the contrary, he can flourish, become an object of biographical pleasure, perhaps even a 'founder of language.' "63

I suggest that we regard, to gain Roland Barthes' sympathy as well, Samuel Beckett, too, as a founder of a sort of language and assess his writing on that basis. I would not like to go to such lengths as a publisher who, while refusing to publish Watt, blamed the Irish air for producing writers like Joyce and Beckett ("It may be that ... we are turning down a potential James Joyce. What is it that this Dublin air does to these writers?"). 64 If not to the air, however, I do attach importance to Beckett's intentions in the final shaping of Watt, for instance.

It appears scarcely questionable that Beckett wished to break down language somehow, he talked about this often himself (in his critical essays or in an interview with Lawrence E. Harvey, for example) and it seems that his bilingualism was an attempted method to reach his goal. Remarkably, he was to come back to English, especially in drama, that is, he "does not reject one language in favour of another, but

62. Sean Burke, The Death and Return of the Author (Edinburgh: Edinburgh University Press, 1998), p. 48.

63. Burke, p. 47.

64. Quoted in Beer, p. 45. 
benefits from the knowledge and use of both in exploring the nature of language itself."65 In a 1937 letter of his (written in German, as a matter of fact), complaining of the pointlessness of writing in English, he compares that language to a veil that has to be torn apart in order that he could reach the thing, or the nothing behind it. "From this letter it is to be suspected that Beckett changed for French for at least two reasons: in the short term he wanted to get rid of Joyce's depressing impact, and eventually, in the long run, he wanted to destroy, what is more, he wanted to eliminate language."66

Watt is perhaps one of the best examples for this endeavour. It parodies language while pushing it to its limits, and also shows the fade-in of French behind an English texture. Unlike Murphy, it goes so far in experimentation that perhaps even its being a work of art is questionable. It is probably "saved" by its rich language and its inimitable humour only. All in all, the novel has a special place in the Beckett world, which is verified by the fact that "as if symbolically, the central character of Watt makes a brief reappearance in the next work of long fiction, having passed from English to French."67

Murphy and Watt, then, appoint the way on the non-existing road leading beyond language. The question remains now only what is to be expected there, what would a writer do if he could realize his plan and destroy language. As far as I see, the question has always been meant to be poetic. The beauty of the problem is exactly that the goal is unrealizable. Beckett, the writer at least, was never able to leave behind languages, though always ready to manipulate his works:

Taking into consideration that the writer interfered in the production of the German version of En attendant Godot, and during working on Malone Dies he eliminated the tone and the expressions that were foreign to the American language, the question might be asked if it is not misleading to call Beckett a bilingual author. It is perhaps more correct to emphasize the purposeful approaching of being between languages in his activity. ${ }^{6}$

65. Beer, p. 41.

66. "Ebből a levélből azt lehet sejteni, hogy Beckett legalábbis két okból tért át a francia nyelvre: rövid távon meg akart szabadulni Joyce nyomasztó hatásától, végső soron, hosszú távon pedig le akarta rombolni, sőt meg akarta szüntetni a nyelvet” (Szegedy-Maszák Mihály, "Kétnyelvűség a huszadik századi irodalomban" [Bilingualism in twentieth-century literature], in Ujraértelmezések [Budapest: Krónika Nova, 2000], pp. 101-110 and 105).

67. Ann Beer, "Beckett's Bilingualism," in The Cambridge Companion to Beckett, ed. John Pilling (Cambridge: Cambridge UP, 1994), 209-221, p. 213.

68. "Ha tekintetbe vesszük, hogy az író beleavatkozott az En attendant Godot német változatának elkészítésébe, a Malone Dies munkálatai során pedig amerikai barátai tanácsára kiik- 
It seems that remaining between languages is his answer to the challenge of reaching the nothing behind them. Nothing as the centre around which he could move in language was not far from him in his early thought, either. In the already mentioned treatise on van Velde's painting "we are shown the impossibility of foundation; there is nowhere to start .... What van Velde in fact is and does was never really on the agenda, and so the whole text has been circling around an absent centre. However deconstructive the logic of his philosophizing may be, Beckett can never quite stop playing the game."69

This thought is of course quite well-known from Derrida's works, indeed, deconstruction as such is probably not far from Beckett's own method, in Hugh Kenner's words "when Beckett wrote Watt, he was busy deconstructing the English novel, with Derrida a mere 14 years old." 70 What I find more significant is, however, that, as the simple fact of writing on and on reflects, Beckett's own journey beyond language was writing itself, he could "convert nothingness into a fertile source of continuous imaginative effort." 71

Beckett can never stop playing the game of talking about absence, that is, as long as he speaks, or writes. It is the theatre that might lead to a sort of solution. The two Acts Without Words manage to place wordless action on the stage, "in Film pantomime totally dominates. Bilingualism can lead to silence."72 Prose writing, however, cannot but yearn for silence. Even if "Beckett's oeuvre is a continuous search for minimal compromise between speaking and keeping quiet, a search for a way of speaking which is false to the least possible degree, a search for true silence which is about something yet," 73 the dwelling place of this true silence can only be approached, but never quite entered with words. It is a place, as Worstward Ho in the grammatically distorted, typically rhythmical style of the latest prose works puts it, "where none. Whither once whence no return. No. No place but the one. None but the one where none. Whence never once in. Somehow in. Beyondless. Thenceless there. Thitherless there. Thenceless thitherless there."74

tatta az amerikai nyelvtől idegen hangnemet és kifejezéseket, föltehető a kérdés, nem félrevezető-e Beckettet kétnyelvű szerzőnek nevezni. Talán helyesebb a nyelvköziség célelvü megközelítését hangsúlyozni a tevékenységében” (Szegedy-Maszák, p. 107).

69. Wood, p. 14.

70. Cahalan, p. 251.

71. Shira Wolosky, "Samuel Beckett's figural evasions," in Languages of the Unsayable, ed. Sanford Budick and Wolfgang Iser (New York: Columbia University Press, 1989), 165-186, p. 184.

72. "A Film-ben a némajáték veszi át a teljes uralmat. A kétnyelvüség csöndhöz vezethet" (Szegedy-Maszák, p. 110).

73. Takács Ferenc, "Utószó,” in Samuel Beckett, Előre Vaknyugatnak, trans. András Barkóczi, Ágnes Klimó et al. (Budapest: Európa, 1989), p. 387.

74. Samuel Beckett, Nohow On (London: John Calder, 1992), p. 104. 